\section{Current status of core needle biopsy of the thyroid}

\author{
Jung Hwan Baek
}

Department of Radiology and Research Institute of Radiology, Asan Medical Center, University of Ulsan College of Medicine, Seoul, Korea

Thyroid nodules are a common clinical problem. Fine-needle aspiration (FNA) and large-needle biopsy have been used to diagnose thyroid nodules [1,2]. Before the 1980s, large-needle biopsy was the standard procedure for the thyroid, but FNA became the standard diagnostic tool in the 1980 s because it is a safe procedure that leads to accurate diagnoses [3]. With advances in core needle biopsy (CNB) devices (i.e., spring-activated core needles) and development of high-resolution ultrasound, it has become possible to make accurate diagnoses while minimizing complications [4]. Although 18- to 21-gauge core needles can be used to biopsy thyroid nodules, 18-gauge needles are most commonly used in Korea $[5,6]$. The relationships among the size of the needle, the number of core specimens, and diagnostic accuracy have not yet been conclusively established, but the general tendency is that thinner needles cause less damage to the normal thyroid, but allow a smaller amount of thyroid tissue to be biopsied to be obtained. These relationships may be validated in the future.

The current guidelines contain limited recommendations for thyroid CNB. The National Cancer Institute, American Association of Clinical Endocrinologists/American College of Endocrinology/ Associazione Medici Endocrinologi (AACE/ACE/AME), and the Korean Society of Thyroid Radiology (KSThR) have proposed CNB for thyroid nodules with previous nondiagnostic FNA results [7-9]. The AACE/ACE/AME, British Thyroid Association, and KSThR have suggested CNB for lymphoma, anaplastic carcinoma, medullary carcinoma, and metastasis to the thyroid [8-10]. However, the American Thyroid Association does not recommend the use of CNB [11].

Recently, CNB has been used for various kinds of thyroid nodules. CNB has been suggested as an alternative to FNA in patients with previous nondiagnostic results [12] or atypia of undetermined significance [13]. It is also useful for the differentiation of rapidly growing thyroid tumors (lymphoma vs. anaplastic thyroid carcinoma), the differentiation of follicular lesions (follicular neoplasm vs. nodular hyperplasia), medullary thyroid carcinoma, calcified thyroid nodules, and degenerating thyroid nodules $[6,14,15]$. Several studies have suggested the value of CNB as a first-line diagnostic tool for the thyroid [16]. According to a meta-analysis [17], both CNB and FNA had a specificity of $99.5 \%$, but the sensitivity was higher for CNB (74\% [95\% confidence interval, $67 \%$ to $81 \%$ ] vs. $50 \%$ [ $95 \%$ confidence interval, $44 \%$ to $56 \%]$ ). CNB also demonstrated significantly fewer nondiagnostic (5.5\%, $\mathrm{P}<0.001)$ and inconclusive $(8.0 \%, \mathrm{P}<0.001)$ results than FNA (22.6\% and $40.2 \%$, respectively). In large cohort studies including more than 500 patients, the false-negative rate ranged from $1 \%$ to $3 \%$ $[16,18,19]$. The main reason for the false-negative results was targeting error.

Regarding the safety of thyroid CNB, current thyroid guidelines suggest that it is safe, welltolerated, and associated with a low complication rate if performed by experienced doctors $[5,7]$. The complication rate has been reported to range from $0 \%$ to $4.1 \%$, with a low major complication rate $(0 \%-1.9 \%)$. Various complications may occur, such as hematoma (the most common complication), voice change, infection, hemoptysis, edema, vasovagal reaction, and dysphagia.

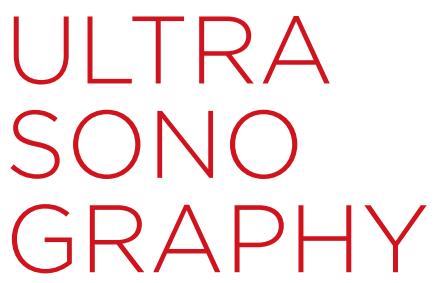

PERSPECTIVE

https://doi.org/10.14366/usg. 17018 pISSN: 2288-5919 • eISSN: 2288-5943 Ultrasonography 2017;36:83-85

Received: February 23, 2017

Revised: March 6, 2017

Accepted: March 8, 2017

Correspondence to: Jung Hwan Baek, MD, PhD, Department of Radiology and Research Institute of Radiology, Asan Medical Center, University of Ulsan College of Medicine, 88 Olympic-ro 43-gil, Songpa-gu, Seoul 05505, Korea

Tel. +82-2-3010-4348

Fax. +82-2-476-0090

E-mail: radbaek@naver.com

This is an Open Access article distributed under the terms of the Creative Commons Attribution NonCommercial License (http://creativecommons.org/ licenses/by-nc/3.0/) which permits unrestricted noncommercial use, distribution, and reproduction in any medium, provided the original work is properly cited.

Copyright (C) 2017 Korean Society of Ultrasound in Medicine (KSUM)

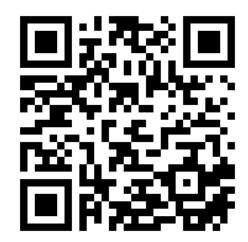

How to cite this article:

Baek JH. Current status of core needle biopsy of the thyroid. Ultrasonography. 2017 Apr;36(2):83-85. 
Recently, a large-scale single-center study analyzed 6,687 nodules from 6,169 patients, and reported no procedure-related deaths, a $0.06 \%$ major complication rate, and a $0.79 \%$ minor complication rate [20]. To minimize complications, CNB should be performed by trained doctors with continuous monitoring of the needle tip using real-time ultrasound. Moreover, knowledge of the neck anatomy, anatomical variations, and potential complications is also required for the safe performance of CNB [21].

As the current evidence for the efficacy and safety of thyroid CNB has grown, the KSThR organized a task force team and released the 2016 Thyroid CNB Guidelines [15]. These guidelines include 11 recommendations regarding indications, the device, the procedure, clinical outcomes, and complications. These guidelines also contain "A Pathology Reporting Proposal of the Korean Endocrine Pathology Thyroid Core Needle Biopsy Study Group" [22]. This categorical reporting system for CNB is similar to the Bethesda system, and is useful to ensure effective communication between pathologists and clinicians, reducing the likelihood of the misinterpretation of pathologic results.

In conclusion, the KSThR has suggested guidelines to improve the efficacy and safety of CNB for diagnosing thyroid nodules. Doctors performing CNB should know the basic CNB techniques and neck anatomy. In the future, it will be necessary to perform validation studies of the role of thyroid CNB according to the KSThR guidelines and new pathologic reporting proposals.

ORICD: Jung Hwan Baek: http://orcid.org/0000-0003-0480-4754

\section{Conflict of Interest}

No potential conflict of interest relevant to this article was reported.

\section{References}

1. Pitman MB, Abele J, Ali SZ, Duick D, Elsheikh TM, Jeffrey RB, et al. Techniques for thyroid FNA: a synopsis of the National Cancer Institute Thyroid Fine-Needle Aspiration State of the Science Conference. Diagn Cytopathol 2008;36:407-424.

2. Silverman JF, West RL, Finley JL, Larkin EW, Park HK, Swanson MS, et al. Fine-needle aspiration versus large-needle biopsy or cutting biopsy in evaluation of thyroid nodules. Diagn Cytopathol 1986;2:25-30.

3. Wang C, Vickery AL Jr, Maloof F. Needle biopsy of the thyroid. Surg Gynecol Obstet 1976;143:365-368.

4. Novoa E, Gurtler N, Arnoux A, Kraft M. Role of ultrasound-guided core-needle biopsy in the assessment of head and neck lesions: a meta-analysis and systematic review of the literature. Head Neck 2012;34:1497-1503.

5. Na DG, Kim JH, Sung JY, Baek JH, Jung KC, Lee $H$, et al. Core- needle biopsy is more useful than repeat fine-needle aspiration in thyroid nodules read as nondiagnostic or atypia of undetermined significance by the Bethesda system for reporting thyroid cytopathology. Thyroid 2012;22:468-475.

6. Yoon RG, Baek JH, Lee JH, Choi YJ, Hong MJ, Song DE, et al. Diagnosis of thyroid follicular neoplasm: fine-needle aspiration versus core-needle biopsy. Thyroid 2014;24:1612-1617.

7. Baloch ZW, Cibas ES, Clark DP, Layfield LJ, Ljung BM, Pitman MB, et al. The National Cancer Institute Thyroid fine needle aspiration state of the science conference: a summation. Cytojournal 2008;5:6.

8. Baek JH, Na DG, Lee JH, Jung SL, Kim JH, Sung JY, et al. Core needle biopsy of thyroid nodules: consensus statement and recommendations. J Korean Soc Ultrasound Med 2013;32:95-102.

9. Gharib H, Papini E, Garber JR, Duick DS, Harrell RM, Hegedus L, et al. American Association of Clinical Endocrinologists, American College of Endocrinology, and Associazione Medici Endocrinologi medical guidelines for clinical practice for the diagnosis and management of thyroid nodules: 2016 update. Endocr Pract 2016;22:622-639.

10. Perros P, Boelaert K, Colley S, Evans C, Evans RM, Gerrard BA, et al. Guidelines for the management of thyroid cancer. Clin Endocrinol (Oxf) 2014;81 Suppl 1:1-122.

11. Haugen BR, Alexander EK, Bible KC, Doherty GM, Mandel SJ, Nikiforov YE, et al. 2015 American Thyroid Association Management Guidelines for adult patients with thyroid nodules and differentiated thyroid cancer: the American Thyroid Association Guidelines Task Force on Thyroid Nodules and Differentiated Thyroid Cancer. Thyroid 2016;26:1-133.

12. Yeon JS, Baek JH, Lim HK, Ha EJ, Kim JK, Song DE, et al. Thyroid nodules with initially nondiagnostic cytologic results: the role of core-needle biopsy. Radiology 2013;268:274-280.

13. Choi YJ, Baek JH, Suh CH, Shim WH, Jeong B, Kim JK, et al. Coreneedle biopsy versus repeat fine-needle aspiration for thyroid nodules initially read as atypia/follicular lesion of undetermined significance. Head Neck 2017;39:361-369.

14. Lee HY, Baek JH, Ha EJ, Park JW, Lee JH, Song DE, et al. Malignantlooking thyroid nodules with size reduction: core needle biopsy results. Ultrasonography 2016;35:327-334.

15. Na DG, Baek JH, Jung SL, Kim JH, Sung JY, Kim KS, et al. Core needle biopsy of the thyroid: 2016 consensus statement and recommendations from Korean Society of Thyroid Radiology. Korean J Radiol 2017;18:217-237.

16. Suh $\mathrm{CH}$, Baek JH, Lee JH, Choi YJ, Kim JK, Sung TY, et al. The role of core-needle biopsy as a first-line diagnostic tool for initially detected thyroid nodules. Thyroid 2016;26:395-403.

17. Suh $\mathrm{CH}$, Baek JH, Lee JH, Choi YJ, Kim KW, Lee J, et al. The role of core-needle biopsy in the diagnosis of thyroid malignancy in 4580 patients with 4746 thyroid nodules: a systematic review and metaanalysis. Endocrine 2016;54:315-328. 
18. Paja M, del Cura JL, Zabala R, Corta I, Lizarraga A, Oleaga A, et al. Ultrasound-guided core-needle biopsy in thyroid nodules: a study of 676 consecutive cases with surgical correlation. Eur Radiol 2016;26:1-8.

19. Sung JY, Na DG, Kim KS, Yoo H, Lee H, Kim JH, et al. Diagnostic accuracy of fine-needle aspiration versus core-needle biopsy for the diagnosis of thyroid malignancy in a clinical cohort. Eur Radiol 2012;22:1564-1572.

20. Ha EJ, Baek JH, Lee JH, Kim JK, Choi YJ, Sung TY, et al. Complications following US-guided core-needle biopsy for thyroid lesions: a retrospective study of 6,169 consecutive patients with 6,687 thyroid nodules. Eur Radiol 2017;27:1186-1194.

21. Ha EJ, Baek JH, Lee JH. Ultrasonography-based thyroidal and perithyroidal anatomy and its clinical significance. Korean J Radiol 2015;16:749-766.

22. Jung CK, Min HS, Park HJ, Song DE, Kim JH, Park SY, et al. Pathology reporting of thyroid core needle biopsy: a proposal of the Korean Endocrine Pathology Thyroid Core Needle Biopsy Study Group. J Pathol Transl Med 2015;49:288-299. 